\title{
PERLAKUAN AKUNTANSI PENDAPATAN DAN PENYAJIANNYA DALAM KEWAJARAN LAPORAN KEUANGAN PADA PT. ANDOWA NATHA WISTARA
}

\author{
Rosmawati $^{1)}$, \\ ${ }^{1)}$ Program Studi Akuntasi, Fakultas Ekonomi Universitas Krisnadwipayana \\ Kampus Unkris Jatiwaringin \\ email:rosmawati@gmail.com \\ Budi Tri Rahardjo ${ }^{2)}$ \\ ${ }^{1)}$ Program Studi Akuntasi, Fakultas Ekonomi Universitas Krisnadwipayana \\ Kampus Unkris Jatiwaringin \\ email:buditrirahardjo@yahoo.com
}

\begin{abstract}
The purpose of this study was to examine the accounting treatment of income and its presentation in the fairness of the financial statements at PT. Andowa Natha Wistara which is located at Sequis Center Building 4th Floor Jl. Jend. Sudirman Kav.71 South Jakarta 12190. The population of this study is the accounting treatment of PT. Andowa Natha Wistara. The sample of this research is the disclosure, measurement and recording at PT. Andowa Natha Wistara. The methods used by researchers in data collection are interviews, observations, and documentation. The technique used in this research is descriptive qualitative analysis. From this research the authors obtained the results that the accounting policy and recognition, and disclosure of measurements applied by PT. Andowa Natha Wistara complies with Statement of Financial Accounting Standards No. 23
\end{abstract}

Keywords: Revenue, Recognition, Measurement

\section{PENDAHULUAN}

Secara umum semua perusahaan baik itu perusahaan industri, dagang maupun jasa tentu memiliki tujuan sama yaitu memperoleh keuntungan pada tingkat tertentu. Untuk memudahkan perusahaan dalam memperoleh keuntungan, pihak manajemen memperoleh informasi berkaitan dengan tujuan yang hendak diraih, maka diperlukan beberapa pengetahuan dan alat yang efektif. Salah satu pengetahuan dan alat yang dimaksud adalah Akuntansi.

Perlakuan akuntansi atas pendapatan merupakan hal yang sangat berkaitan dengan kegiatan operasional perusahaan, dimana pendapatan merupakan suatu hasil yang diperoleh dari kegiatan perusahaan. Untuk memperoleh laba yang akurat, maka arus pendapatan harus diterapkan dengan baik yaitu sesuai dengan prinsip akuntansi.

Permasalahan utama dalam akuntansi untuk pendapatan adalah menentukan saat pengakuan pendapatan. Pada prinsip pengakuan pendapatan, umumnya pendapatan diakui pada saat direalisasikan atau dapat direalisasikan dan dihasilkan. Keakuratan dalam pengakuan pendapatan ini akan sangat berpengaruh pada besarnya pendapatan yang akan disajikan dalam laporan keuangan yang tentu saja akan berpengaruh terhadap jumlah laba yang akan diperoleh pada periode tersebut.

Selain pendapatan yang diakui sebagai rugi laba perusahaan, setiap perusahaan pasti memiliki rencana keuangan yang berbeda-beda. Saat ini semua perusahaan wajib membuat suatu laporan yang berkaitan dengan perkembangan keuangan perusahaan dalam suatu periode tertentu. Aktivitas ini selalu terjadi secara terus menerus dan system pencatatanya disesuaikan dengan prosedur yang berlaku pada masingmasing perusahaan tersebut.

Laporan keuangan dalam suatu perusahaan dibuat dengan maksud memberikan gambaran kemajuan tersebut secara periodik. Dengan demikian prosedur pencatatan akuntansi yang benar menjadi suatu keharusan dalam penyusunan laporan keuangan yang dapat diandalkan.

Mengingat sangat pentingnya laporan keuangan, maka hendaknya pimpinan maupun pihak menajemen perusahaan PT. Andowa Natha 
Printed ISSN 2406-7415

e-ISSN 2655-9919

Jurnal Akuntansi \& Bisnis Krisnadwipayana

Vol. 6 No. 2 (Mei - Agustus) 2019

Wistara dapat menjalankan kebijakan pengawasan dengan baik. Untuk tercapainya suatu pengawasan yang baik diperlukan alat control yang efektif untuk mengelola jalannya operasi perusahaan sesuai dengan yang telah direncanakannya.

Salah satu caranya dengan Kebijakan Akuntansi Pencatatan, Penyajian dan pengungkapan Laporan Keuangan Pendapatan yang sesuai dengan kaidah Akuntansi yang berlaku yaitu sesuai dengan Standar Akuntansi Keuangan (SAK). Standar Akuntansi Keuangan memberikan fleksibilitas bagi manajemen dalam memilih metode maupun estimasi akuntansi yang akan digunakan, fleksibilitas tersebut akan mempengaruhi transaksi keuangan perusahaan.

Terkadang aktivitas perusahaan dilingkupi dengan sebuah ketidakpastian, maka pencatatan akuntansi dan laporan keuangan menjadi sebuah pertimbangan. Dengan ini suatu perusahaan dapat mengetahui pendapatan dalan waktu tertentu, mengetahui laba dan rugi dengan cepat.

\section{TINJAUAN PUSTAKA}

\section{Akuntansi}

Sujarweni (2016:1) Akuntansi adalah proses dari transaksi yang dibuktikan dengan faktur, lalu dari transaksi dibuat jurnal, buku besar, neraca lajur, kemudian akan menghasilkan informasi dalam bentuk laporan keuangan yang digunakan pihak-pihak tertentu.

Terdapat dua aspek penting dalam akuntansi, yaitu Aspek Fungsi dan Aspek Aktivitas.

Karakteristik penting akuntansi, meliputi:

1. Pengindentifikasian, pengukuran, dan pengomunikasian, informasi keuangan.

2. Akuntansi sebagai suatu system dengan input data/informasi dengan output informasi dan laporan keuangan.

3. Informasi keuangan terkait suatu entitas.

4. Informasi dikomunikasikan untuk pemakai untuk pengambilan keputusan.

Pihak-pihak yang membutuhkan dan senantiasa menggunakan informasi akuntansi, yaitu: Pihak Internal, Investor, Pemegang saham/pemilik perusahaan, Pemerintah, Kreditur dan Pihak lainnya.

\section{Pendapatan}

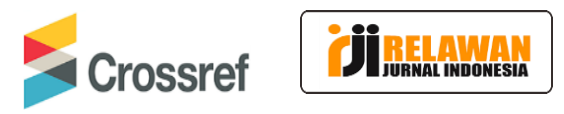

Terdapat dua pendekatan terhadap konsep pendapatan yang dapat ditemukan dalam literature akuntansi.

1. Pendekatan yang memusatkan pada arus masuk (inflow) asset yang ditimbulkan oleh kegiatan operasional perusahaan, dimana pendapatan akan diakui pada saat itu juga atau pada saat terjadinya penjualan, yaitu pada saat terjadinya arus masuknya asset baru sebagai akibat dari hasil akhir kegiatan operasional dan besarnya pendapatan itu dapat diukur menurut nilai dari asset yang masuk tersebut.

2. Pendekatan yang memusatkan perhatian pada penciptaan barang dan jasa serta penyalurannya kepada konsumen atau produsen lainnya, misalnya kepada para perusahaan kontraktor di mana dalam mengerjakan kontrak jangka panjang dengan menggunakan persentase penyelesaian dalam mengakui pendapatannya, maka pendapatan akan diakui sesuai dengan besarnya jasa yang telah dikerjakan atau juga pekerjaan yang telah diselesaikan dan harus diakui pada saat itu.

\section{Sumber dan Penggolongan Pendapatan}

Berdasarkan sumber pendapatan tersebut diperoleh, pendapatan dapat dikelompokkan menjadi:

1. Pendapatan Usaha, yaitu pendapatan yang diperoleh dari hasil usaha pokok atau utama perusahaan: pendapatan usaha/jasa, penjualan barang dagangan/hasil produksi.

2. Pendapatan di Luar Usaha/Pendapatan LainLain (The Other Income), yaitu pendapatan yang diperoleh dari hasil di luar usaha pokok atau utama perusahaan seperti pendapatan bunga, pendapatan sewa (rent income) dan penjualan asset tetap (gain on sales of fixed assets).

Dalam Pernyataan Standar Akuntansi Keuangan No. 23 (2015:01) Pernyataan ini harus ditetapkan dalam akuntansi untuk pendapatan timbul dari transaksi dan peristiwa ekonomi sebagai berikut: Penjualan barang, Penjualan jasa, dan Penggunaan asset entitas oleh pihak lain yang menghasilkan bunga, royalty dan deviden.

\section{Kebijakan Akuntansi tentang Pengakuan} Pendapatan 
Printed ISSN 2406-7415

e-ISSN 2655-9919

Jurnal Akuntansi \& Bisnis Krisnadwipayana

Vol. 6 No. 2 (Mei - Agustus) 2019

Kegiatan operasi perusahaan adalah proses yang terus menerus yang merupakan langkah-langkah untuk memperoleh pendapatan. Ketentuan utama dan beberapa ketentuan tambahan pengakuan pendapatan yaitu sebagai berikut :

1. Pengakuan pada titik penyerahan perusahaan

2. Pengakuan pada saat pembayaran

Hasil suatu transaksi dapat diestimasikan dengan andal bila seluruh kondisi berikut dipenuhi:

1. Jumlah pendapatan dapat diukur secara andal

2. Besar kemungkinan manfaat ekonomi sehubungan dengan transaksi tersebut akan mengalir ke entitas

3. Tingkat penyelesaian dari suatu transaksi pada akhir periode pelaporan dapat diukur secara andal.

4. Biaya yang timbul untuk transaksi dan biaya untuk menyelesaikan transaksi tersebut dapat diukur secara andal.

Secara teoritis ketepatan waktu pengakuan pendapatan dapat keadaan saat seperti :

1. Selama berlangsungnya produksi : ini terlihat pada kontrak-kontrak pembangunan yang bersifat jangka panjang, pada proses peningkatan nilai secara alamiah (accretion), dan accruals.

2. Pada saat penjualan ini adalah timing dari revenue untuk kebanyakan barang yang dijual.

3. Pada saat diterimanya uang tunai : misalnya, terjadi pada penjualan dengan cicilan.

4. Sesudah produksi selesai : misalnya, dapat dijumpai dalam produksi logam mulia dan komoditi-komiditi pertanian.

Sebagai ketentuan umum, pendapatan diakui pada saat realisasinya, atau dapat dijabarkan sebagai berikut :

1. Pendapatan dari penjualan produk diakui pada tanggal penjualan, biasanya merupakan tanggal penyerahan produk kepada pelanggan.

2. Pendapatan atas jasa yang diberikan oleh perusahaan jasa diakui pada saat jasa tersebut telah dilakukan dan dapat dibuat fakturnya.

3. Imbalan yang diperoleh atas penggunaan aset/sumber ekonomi perusahaan oleh pihak lain seperti: pendapatan sewa, bunga dan royalti diakui sejalan dengan berlakunya waktu atau pada saat digunakan aset tersebut.

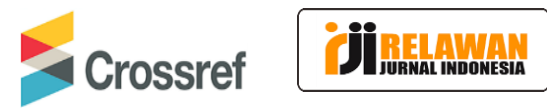

4. Pendapatan dari penjualan aset diluar barang dagangan seperti penjualan aset tetap atau surat berharga, diakui pada tanggal penjualannya.

Sebagai aturan umum pelaporan pendapatan dalam akuntansi meliputi, Bukti Obyektif yang dapat diperiksa, Konvensi, dan Kepastian.

Dalam hal tertentu, dimungkinkan untuk melakukan penyimpangan dalam pencatatan pendapatran dari ketentuan umum seperti dikemukakan di atas, antara laian :

1. Pendapatan diakui pada saat pembayaran diterima atau sesudah terjadinya penjualan.

2. Pengakuan pendapatan pada penjualan konsinyasi.

3. Pengakuan pendapatan pada saat selesai produksi.

4. Pengakuan pendapatan selama produksi atau pengakuan secara proposional dengan tahapan produksi.

Pelaporan dan Pengungkapan Pendapatan

Pengungkapan pendapatan menurut

Pernyataan Standar Akuntansi Keuangan No. 23 (2015:35) entitas harus mengungkapkan pendapatan adalah sebagai berikut :

"Kebijakan akuntansi yang digunakan untuk pengakuan pendapatan termasuk metode yang digunakan untuk menentukan tingkat penyelesaian transaksi penjualan jasa."

"Jumlah setiap kategori signifikan dari pendapatan diakui selama periode tersebut termasuk pendapatan yang berasal dari penjualan barang, penjualan jasa, bunga, royalti, dan dividen"

\section{Laporan Keuangan}

Menurut PSAK No. 1 (2015:1), "Laporan

keuangan adalah penyajian terstruktur dari posisi keuangan dan kinerja keuangan suatu entitas."

Laporan Keuangan menurut Hery

(2013:19) adalah sebagai berikut :

"Hasil dari proses akuntansi yang dapat digunakan sebagai alat untuk mengkomunikasikan data keuangan atau aktivitas perusahaan kepada pihak-pihak yang berkepentingan."

Kemudian menurut Subramanyam (2012:79) Laporan Keuangan adalah sebagai berikut : 
Printed ISSN 2406-7415

e-ISSN 2655-9919

Jurnal Akuntansi \& Bisnis Krisnadwipayana

Vol. 6 No. 2 (Mei - Agustus) 2019

"Produk proses pelaporan keuangan yang diatur oleh standar dan aturan akuntansi, insentif manajer, serta mekanisme pelaksanaan dan pengawasan perusahaan". Adapun pihak-pihak yang berhubungan

dengan perusahaan adalah :

1. Kreditor

2. Pemerintah

3. Calon Investor

4. Pemasok (Supplier)

5. Pemilik/Pemegang Saham

6. Manajer ProduksiManajer Pemasaran

7. Pihak internal perusahaan

8. Berbagai pihak internal perusahaan lainnya Menurut Standar Akuntansi Keuangan pada ruang lingkup Laporan Keuangan (2015:1) adalah :

"Laporan Keuangan merupakan bagian dari proses pelaporan keuangan. Laporan keuangan yang lengkap biasanya meliputi neraca, laporan laba rugi, laporan perubahan posisi keuangan (yang dapat disajikan dalam berbagai cara, sebagai contoh, sebagai laporan arus kas, atau laporan arus dana), catatan dan laporan lain serta materi penjelasan yang merupakan bagian integral dari laporan keuangan. Disamping itu juga termasuk skedul dan informasi tambahan yang berkaitan dengan laporan tersebut, sebagai contoh, informasi keuangan segmen industri dan geografis serta perangkapan pengaruh perubahan harga."

\section{Tujuan Umum Laporan Keuangan}

Secara umum, tujuan Laporan Keuangan adalah menyediakan informasi tentang posisi keuangan, kinerja keuangan, dan laporan arus kas entitas yang bermanfaat bagi sejumlah besar pengguna dalam pengambilan keputusan ekonomi atau siapapun yang tidak dalam posisi dapat meminta laporan keuangan khusus untuk memenuhi kebutuhan informasi tertentu.

Menurut Standar Akuntansi Keuangan (2015) menyatakan bahwa tujuan Laporan Keuangan adalah :

"Menyediakan informasi yang menyangkut posisi keuangan, kinerja serta perubahan posisi keuangan suatu entitas yang bermanfaat bagi sejumlah besar

\section{Crossref idinemanan}

pengguna dalam pengambilan keputusan ekonomik".

Dalam memenuhi tujuannya, laporan keuangan juga menunjukkan apa yang telah dilakukan manajemen (stewardship) atau pertanggungjawaban manajemen atas sumber daya yang dipercayakan kepadanya.

Walaupun satu badan usaha memiliki bidang usaha dan karekteristik yang berbeda satu dengan lainnya, secara umum laporan keuangan disusun dengan tujuan yang sama. Tujuan penyajian laporan keuangan oleh sebuah entitas dapat dirinci sebagai berikut :

1. Untuk memberikan informasi keuangan yang dapat dipercaya mengenai sumber-sumber ekonomi dan kewajiban serta modal perusahaan

2. Untuk memberikan informasi yang dapat dipercaya mengenai perubahan sumbersumber ekonomi perushaan yag timbul dalam aktvitas usaha demi memperoleh laba.

3. Untuk memberikan informasi keuangan yang membantu para pemakai laporan untuk mengestimasi potensi perusahaan dalam menghasilkan laba di masa depan.

4. Untuk memberikan informasi keuangan yang membantu para pemakai laporan ketika mengestimasi potensi perusahaan dalam menghasilkan laba.

5. Untuk memberikan informasi penting lainnya mengenai perubahan sumber-sumber ekonomi dan kewajiban, seperti informasi tentang aktivitas pembiayaan dan investasi.

6. Untuk mengungkapkan sejauh mungkin informasi lain yang berhubungan dengan laporan keuangan yang relevan untuk kebutuhan pemakai laporan, seperti informasi mengenai kebijakan akuntansi yang dianut perusahaan.

Kasmir (2012:10) menyatakan bahwa tujuan Laporan Keuangan adalah:

1. Memberikan informasi tentang jenis dan jumlah aktiva (harta) yang dimiliki oleh perusahaan pada saat ini

2. Memberikan informasi tentang jenis dan jumlah kewajiban dan modal yang dimiliki oleh perusahaan pada saat ini.

3. Memberikan informasi tentang jenis dan jumlah pendapatan yang diperoleh pada suatu periode tertentu. 
Printed ISSN 2406-7415

e-ISSN 2655-9919

Jurnal Akuntansi \& Bisnis Krisnadwipayana

Vol. 6 No. 2 (Mei - Agustus) 2019

4. Memberikan informasi tentang jumlah biaya dan jenis biaya yang dikeluarkan oleh perusahaan dalam suatu periode tertentu.

5. Memberikan informasi tentang kinerja manajemen perusahaan dalam suatu periode tertentu

6. Memberikan informasi tentang catatan catatan atas laporan keuangan

7. Informasi keuangan lainnya.

Dalam rangka mencapai tujuan tersebut,

suatu laporan keuangan menyajikan informasi mengenai perusahaan meliputi, Aset, Kewajiban, Ekuitas, Pendapatan dan beban termasuk keuntungan, dan Arus kas

Informasi tersebut di atas beserta informasi lainnya yang terdapat dalam catatan laporan keuangan membantu pengguna laporan dalam memprediksi arus kas masa depan, khususnya dalam hal waktu dan kepastian diperolehnya kas dan setara kas.

Laporan Keuangan juga merupakan ringkasan dari proses akuntansi selama tahun buku yang bersangkutan yang digunakan sebagai alat untuk berkomunikasi antara data keuangan atau aktivitas suatu perusahaan dengan pihakpihak yang berkepentingan terhadap data atau aktivitas suatu perusahaan karena pada umumnya, laporan keuangan terdiri dari neraca dan perhitungan laba rugi serta laporan perubahan posisi keuangan dan catatan atas laporan keuangan.

Laporan Keuangan dibuat untuk mengatasi masalah yang akan timbul karena dengan Laporan Keuangan tersebut perusahaan dapat mengetahui berapa untung dan ruginya sebelum perusahaan mengambil keputusan untuk berhenti atau dilikuidasi.

Selain itu juga dapat mengetahui sampai seberapa jauh tingkat kemajuan perusahaan dan juga dapat membantu dalam usaha perkembangan perusahaan selanjutnya.

\section{Konsep-Konsep Akuntansi dalam Laporan Keuangan}

Sebagai alat bantu manajemen, Akuntansi dapat memberikan informasi tentang kondisi keuangan dan hasil operasi perusahaan. Hal tersebut dihasilkan dari akuntansi yaitu sebuah laporan keuangan tersebut, sehingga laporan keuangan dapat dipakai sebagai alat komunikasi dengan pihak-pihak yang berkepentingan dengan

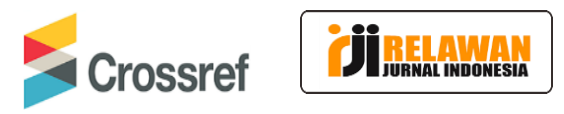

data keuangan perusahaan yang dinyatakan secara kuantitatif dalam satuan uang, dan disusun dengan maksud untuk menyediakan informasi keuangan perusahaan kepada yang berkepentingan sebagai bahan pertimbangan dalam pengambilan keputusan.

Setiap perusahaan memiliki bidang usaha dan karekteristik yang berbeda satu dengan lainnya, sehingga rincian laporan keuangan satu perusahaan dengan perusahaan lainnya juga berbeda. Namun, laporan keuangan yang dihasilkan oleh setiap institusi harus memenuhi standar kualitas berikut ini agar bermanfaat:

1. Dapat Dipahami

2. Relevan

3. Materialitas

4. Keandalan/Reliabilitas

5. Substansi Mengungguli Bentuk

6. Pertimbangan yang Sehat

7. Kelengkapan

8. Dapat dibandingkan/Komparabilitas

9. Tepat Waktu

10.Keseimbangan antara Biaya dan Manfaat

Laporan keuangan yang dihasilkan mempunyai beberapa keterbatasan seperti , Cukup berarti, Konservatif, dan Sifat khusus suatu industri

Konsep-konsep yang melandasi Neraca

Konsep-konsep yang yang melandasi penyusunan neraca adalah sebagai berikut :

1. Konsep konsistensi (consistency concepts)

2. Konsep unit pengukuran (measurement concepts)

3. Konsep kesatuan usaha (business entity concepts)

4. Konsep kelangsungan hidup (going concern concepts)

5. Konsep harga pokok (cost concepts)

Dalam neraca dapat diketahui berapa jumlah kekayaan perusahaan, kemampuan perusahaan membayar kewajiban serta kemampuan perusahaan memperoleh tambahan pinjaman dari pihak luar, selain itu juga dapat mengetahui informasi mengenai hutang perusahaan.

\section{Konsep-konsep dalam Perhitunga Laba-Rugi}

Laporan laba rugi adalah laporan yang menunjukkan hasil usaha dan biaya-biaya selama suatu periode akuntansi sedangkan yang dimaksud dengan laba rugi adalah selisih jumlah penerimaan dengan jumlah biaya produksi. 
Printed ISSN 2406-7415

e-ISSN 2655-9919

Jurnal Akuntansi \& Bisnis Krisnadwipayana

Vol. 6 No. 2 (Mei - Agustus) 2019

Konsep laba/rugi yaitu sebagai berikut :

1. Jika biaya lebih kecil dari penerimaan, maka akan lahir konsep laba.

2. Jika biaya lebih besar dari penerimaan, maka akan lahir konsep rugi.

3. Jika biaya lebih sama dengan penerimaan, maka akan lahir konsep impas (break even point).

Dimana konsep-konsep dasar akuntansi harus dipakai dalam penyusunan perhitungan laba rugi, yaitu :

1. Konsep konservatif (conservatism concepts).

2. Konsep materialitas (materiality concepts).

3 . Konsep pengungkapan yang memadai.

4. Konsep penandingan (matching concepts)

5. Konsep periode waktu (time period concepts)

Jadi, laporan laba rugi merupakan ikhtisar mengenai pendapatan dan beban suatu perusahaan untuk periode atau waktu tertentu sehingga dapat diketahui laba yang diperoleh serta rugi yang dialami.

\section{METODE PENELITIAN}

Objek dalam penelitian ini adalah Perlakuan Akuntansi Pendapatan Dan Penyajiannya Dalam Kewajaran Laporan Keuangan. Lokasi penelitian adalah PT. Andowa Natha Wistara yang beralamat di Gedung Sequis Center Lantai 4 Jl. Jend. Sudirman Kav.71 Jakarta Selatan 12190.

Populasi penelitian ini adalah perlakuan akuntansi PT. Andowa Natha Wistara. Sampel dari penelitian ini adalah pengungkapan, pengukuran dan pencatatan pada PT. Andowa Natha Wistara.

Metode yang digunakan peneliti dalam pengumpulan data adalah Interview, Observasi, dan Dokumentasi. Setelah data-data diperoleh, kemudian data tersebut diolah dan dianalisis. Teknik yang digunakan dalam penelitian ini adalah analisis deskriptif kualitatif dengan mendeskripsikan atau menggambarkan keadaan objek penelitian yang sesungguhnya untuk mengetahui dan menganalisis permasalahan yang dihadapi oleh objek penelitian kemudian dibandingkan dengan standar yang ada pada saat itu. Menganalisis Perlakuan Akuntansi Pendapatan PT. Andowa Natha Wistara meliputi

1. Pengakuan dan Pengukuran Pendapatan

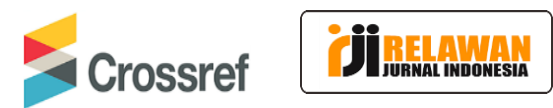

2. Pencatatan dan Pengungkapan

3. Penyajian pada Laporan Keuangan

\section{HASIL DAN PEMBAHASAN Hasil Penelitian Pengakuan Pendapatan}

Pendapatan dari pesanan pekerjaan atau pengadaan diakui pada saat adanya transaksi keuangan atau penerimaan kas. Pada saat pembayaran uang muka pesanan belum diakui sebagai pendapatan, setelah barang selesai dan diserahkan kepada pemesan oleh perusahaan dan telah dilunasi (pembayaran) sisanya oleh pemesan, maka saat itu perusahaan akan mencatatnya sebagai pendapatan.

\section{Pengukuran Pendapatan}

Pendapatan PT. Andowa Natha Wistara diukur dengan nilai wajar imbalan yang diterima atau yang dapat diterima oleh PT. Andowa Natha Wistara.

Perlakuan Akuntansi Pendapatan PT. Andowa Natha Wistara

\section{Kebijakan Akuntansi}

Pendapatan diakui pada saat order diterima dengan dikeluarkannya surat pesanan dan Down Payment diterima, sedangkan pelunasan diterima pada saat barang diserahkan ke konsumen dengan dilampiri surat uji fungsi barang dengan hasil baik.

\section{Pencatatan Pendapatan}

a. Pengadaan Peralatan Pendukung Secure Data Exploration

Pada tanggal 23 Agustus 2013, Lembaga Sandi Negara membuat pesanan atas barang secure data exploration senilai Rp 29.927.000.000,-. Pada tanggal 5 September 2013 Lembaga Sandi Negara membayar Down Payment (DP) 20\% sebesar Rp 5.359.653.636 (dipotong PPh 22 dan PPN)

Dr: Kontrak 29.927.000.000

$\mathrm{Cr}$ : Penjualan 27.206.363.636

Cr: PPN 2.720.636.364

Dr : Bank $\quad 5.359 .653 .636$

Dr: PPh 22

81.619 .091

Dr : PPN

544.127 .273

Cr : Uang Muka Kontrak 5.985.400.000 
Printed ISSN 2406-7415

e-ISSN 2655-9919

Jurnal Akuntansi \& Bisnis Krisnadwipayana

Vol. 6 No. 2 (Mei - Agustus) 2019

Pada tanggal 3 Desember 2013, terima pelunasan $(80 \%)$ sebesar $\mathrm{Rp}$. 21.438.614.545,- (dipotong Pph 22 dan PPN)

Dr : Bank

21.438.614.545

Dr: PPh 22 326.476 .364

Dr : PPN Keluar

2.176.509.091

$\mathrm{Cr}$ : Non Trade Aff

Rec.Kontrak

23.941.600.000

b. Pengadaan Integrated Audio Visual Intelligent System

Pada tanggal 12 Agustus 2014, Badan Intelligent Strategis membuat pesanan atas barang Intelligent System senilai $\quad \mathrm{Rp}$ 19.967.426.000,-.
$\mathrm{Cr}$ : Sales
18.152.205.454,5
$\mathrm{Cr}$ : PPN Keluar
1.815.220.545,5

Pada tanggal 19 September 2014 Badan Intelligent Strategis membayar Down Payment (DP) $\quad 20 \% \quad$ sebesar Rp 3.993.485.200

Dr : Bank 3.993.485.200

$\mathrm{Cr}$ : DP $20 \% \mathrm{Bz}$ 3.993 .485 .200

Kemudian pada tanggal 10 Desember 2014, diterima pembayaran atas pelunasan pekerjaan $80 \%$ sebesar $\mathrm{Rp}$ 13.886.437.150,- (dipotong PPh 22 dan PPN)
Dr : Bank
13.886.437.150
Dr : PPh 22
272.283.081,82
Dr : PPN
$1.815 .220 .545,45$
Dr : Pembulatan
22,73
$\mathrm{Cr}$ : Pelunasan $80 \% \quad 15.973 .940 .800$

c. Pengadaan Integrated Audio Visual Intelligent System

Pada tanggal 12 Agustus 2014, Badan Intelligent Strategis membuat pesanan atas barang Security System senilai Rp 32.860.900.000,-. Pada tanggal 22 Oktober 2014 Badan Intelligent Strategis membayar Down Payment (DP) 20\% sebesar Rp 6.572.180.000 (dipotong Pph 22dan PPN)

Dr : Proyek BZ

32.860 .900 .000

$\mathrm{Cr}:$ Sales 29.873.545.454,5

$\mathrm{Cr}$ : PPN Keluar

2.987.354.545,45

\section{Crossref}

Dr : Bank

5.885 .088 .400

Dr : PPN Keluar

597.470 .950

Dr: Pph 22

Cr : Proyek BZ

89.620 .650

6.572 .180 .000

Kemudian pada tanggal 14 Januari 2015, diterima pembayaran atas pelunasan pekerjaan $80 \%$ sebesar $\mathrm{Rp}$ 16.288.720.000,- (dipotong PPh 22 dan PPN dan pinalti atas pekerjaan sebesar Rp.1.000.000.000)

Dr : Bank 13.468.729.800

Dr : PPN $2.389 .883 .595,45$

Dr : Pph 22 $358.482 .545,45$

Dr : Pembulatan

$71.624 .059,1$

Cr : Pelunasan $80 \% \quad 16.288 .720 .000$

\section{Penyajian dan Pengungkapan}

Berdasarkan data yang diperoleh maka dapat diperoleh informasi bahwa Kas dan Bank disajikan dalam Laporan Keuangan (Neraca), sedangkan Pendapatan disajikan dalam Laporan Keuangan (Laba/Rugi). Selain itu dari Perlakuan Akuntansi (kebijakan akuntansi, pencatatan dan penyajian Laporan Keuangan) yang diterapkan oleh PT. Andowa Natha Wistara telah sesuai dengan Pernyataan Standar Akuntansi Keuangan No.23.

\section{KESIMPULAN DAN SARAN Kesimpulan}

Dari hasil penelitian ini, maka penulis akan menarik suatu kesimpulan, antara lain sebagai berikut :

1. Kebijakan Akuntansi yang diterapkan oleh PT. Andowa Natha Wistara telah sesuai dengan Pernyataan Standar Akuntansi Keuangan No. 23

2. Pengakuan dan Pengukuran Pendapatan pada PT. Andowa Natha Wistara telah sesuai dengan Pernyataan Standar Akuntansi Keuangan No. 23. Dimana pengakuan pendapatan perusahaan menggunakan Metode Accrual Basis yakni pendapatan diakui pada saat terjadinya transaksi penjualan jasa oleh perusahaan.

3. Pengungkapan Pendapatan pada Laporan Keuangan yang disajikan telah sesuai dengan Pernyataan Standar Akuntansi Keuangan No.23

\section{Saran}


Printed ISSN 2406-7415

e-ISSN 2655-9919

Jurnal Akuntansi \& Bisnis Krisnadwipayana

Vol. 6 No. 2 (Mei - Agustus) 2019

Penulis akan memberikan saran bagi perusahaan, agar dapat dijadikan bahan dasar pertimbangan untuk menentukan keputusan yang akan diambil.

1. Sebaiknya Perlakuan Akuntansi Pendapatan PT. Andowa Natha Wistara mengakui pendapatan secara akrual dan konsisten, karena mudah untuk menjadwalkan kapan pendapatan itu akan diterima. Sehingga pendapatan dapat dikelola dengan baik.

2. Administrasi Akuntansi yang ada saat ini sebaiknya lebih ditingkatkan lagi secara berkelanjutan, sehingga laporan keuangan yang disajikan sesuai dengan standart atau ketentuan yang berlaku.

\section{DAFTAR PUSTAKA}

Amri Setiono, Suhadak, Nengah Sujana, 2015, Metode Pengakuan Pendapatan dan Beban Terhadap kewajaran Laporan Keuangan, Jurnal Administrasi Bisnis Vol 24 No. 1Juli 2015, Gresik

Dina Fitria, 2012, Buku Pintar Akuntansi, Jakarta : Laskar Aksara

Fahmi, Irham, 2012, Pengantar Pasar Modal, Bandung : Alfabeta

Hery, 2013, Teori Akuntansi Suatu Pengantar, Jakarta : Lembaga Penerbit Fakultas Ekonomi Universitas Indonesia

Ikatan Akuntansi Indonesia, Pernyataan Standar Akuntansi Keuangan, 2015

Kadek Arsani, I Wayan Putra, 2013, Perlakuan Akuntansi Pendapatan dan Beban Berbasis SAK ETAP dan Implikasinya pada Laporan Keuangan KSP Duta Sejahtera, E-Jurnal Akuntansi Universitas Udayana, Bali

Kasmir, 2012, Analisis Laporan Keuangan, Jakarta : PT Raja Grafindo Persada

Kieso, Donald E Weygandt, Jery J Warfield, \& Terry D, 2012, Akuntansi Intermediate, Jakarta : Erlangga

Rina Susilawati, Tri Lestari, Achmad Usman, 2014, Penerapan Metode Pengakuan Pendapatan dan Beban Terhadap Kewajaran Laporan Keuangan PG. Watoetoelis, Sidoarjo

Rudianto, 2012, Pengantar Akuntansi, Jakarta : Erlangga
Subramanyam , 2014, Analisis Laporan

Keuangan - Financial Statement, Buku 1

Edisi 10, Jakarta : Salemba Empat 
Printed ISSN 2406-7415

e-ISSN 2655-9919

Jurnal Akuntansi \& Bisnis Krisnadwipayana

Vol. 6 No. 2 (Mei - Agustus) 2019 